\title{
Distribution and Interrelationship of Ubiquitin Proteasome Pathway Component Activities and Ubiquitin Pools in Various Porcine Tissues
}

\author{
M. B. PATEL, M. MAJETSCHAK \\ Divisions of Trauma and Surgical Critical Care, DeWitt Daughtry Family Department of Surgery, \\ University of Miami, Miller School of Medicine, Miami, FL, USA
}

Received April 18, 2006

Accepted June 20, 2006

On-line available June 22, 2006

\begin{abstract}
Summary
The ubiquitin-proteasome pathway fulfills major biological functions, but its physiologic tissue distribution and the interrelationship between pathway component activities and ubiquitin pools are unknown. Therefore, we analyzed free and conjugated ubiquitin, ubiquitin-protein ligation rates (UbPL) and chymotryptic- and tryptic-like proteasome peptidase activities in porcine skeletal muscle, heart, lung, liver, spleen and kidney ( $\mathrm{n}=5$ each). There were considerable differences between tissues ( $<<0.05$ for all parameters). Lung and spleen showed high levels of free and conjugated ubiquitin and high UbPL. Proteasome activities were highest in kidney and heart. There were linear relationships between tryptic-like and chymotryptic-like proteasome peptidase activities $\left(r^{2}=0.624, p<0.001\right)$ and between free and conjugated ubiquitin tissue levels $\left(r^{2}=0.623, p<0.001\right)$. Tissue levels of free and conjugated ubiquitin correlated linear with UbPL $(\mathrm{p}<0.005)$, but they were not correlated with proteasome peptidase activities. The results suggest that tissue ubiquitin pools are tightly regulated and indicate a constant proportion of conjugated ubiquitin. They further support the hypothesis that ubiquitin-protein ligase systems, and probably deubiquitylating enzymes, are key regulators of ubiquitin homeostasis. The detected differences are suggestive of tissue-specific roles of ubiquitin-proteasome pathway components. Besides the known importance of the ubiquitin proteasome pathway in heart, kidney and the immune system, the results suggest the lung as another organ in which ubiquitin proteasome pathway components may also significantly contribute to disease processes.
\end{abstract}

\section{Key words}

Proteasome • Ubiquitin protein ligase system • Ubiquitin • Ubiquitin protein conjugates • Tissue distribution • Ubiquitin homeostasis

\section{Introduction}

The ubiquitin proteasome pathway of protein degradation regulates essential cellular functions (Hershko and Ciechanover 1998) and data on its possible contribution to various disease states accumulate 
exponentially. In the ubiquitin proteasome pathway, the ubiquitin-protein ligase systems, which traditionally consist of a ubiquitin activating enzyme (E1), a ubiquitin carrier or conjugating enzyme (E2) and a ubiquitin protein ligase (E3) (Hershko and Ciechanover 1998), catalyze the covalent ligation of ubiquitin to intracellular proteins (i.e. ubiquitination or ubiquitylation). The ubiquitylated protein is then destined for degradation by the multicatalytic $\mathrm{Mg}^{2+} / \mathrm{ATP}-$ dependent $26 \mathrm{~S}$ proteasome, which consists of the 20S proteasome, comprising the proteolytic core, and capped by two 19S regulators, which confer $\mathrm{Mg}^{2+} /$ ATP-dependency and ubiquitylated substrate specificity (Orlowski 1990, Rivett 1993 Baumeister et al. 1998, Hershko and Ciechanover 1998). Besides its catabolic role in the ubiquitin proteasome pathway, ubiquitylation emerged as a non-proteolytic reversible modification that also controls essential intracellular functions, including DNA repair, protein kinase activation, and endocytic trafficking. Today ubiquitylation is regarded as the second most common posttranslational modification following phosphorylation (Weissman 2001, Ben-Neriah 2002, Sigismund et al. 2004)

It is known that free ubiquitin exists in a rapid and complex equilibrium with multiple conjugated forms and that maintenance of ubiquitin homeostasis is essential for cell viability (Haas and Bright 1987, Hanna et al. 2003). However, the regulation of the cellular ubiquitin pool is insufficiently understood.

Studies on the role of the ubiquitin proteasome system and its involvement in the maintenance of ubiquitin homeostasis are hampered by the fact that the functional relevance of protein or mRNA levels of its multiple enzyme components is unclear (Hasselgren 2000, Jagoe and Goldberg 2001, DeRuisseau et al. 2005). Thus, data on its activities are mandatory to assess its role in health and disease.

Fluorogenic peptide substrates in combination with proteasome inhibitors have been widely used to assess proteasome peptidase activities in individual tissue or cell culture extracts (Rodgers and Dean 2003, Kukan 2005, Kisselev and Goldberg 2005), but information on their distribution among different tissues is limited. Even less information is available on the activity of ubiquitin protein ligase systems in tissue or cell culture extracts. Its physiologic tissue distribution and interrelationship with proteasome activities and the tissue ubiquitin pools are unknown.

Therefore, it was the aim of the present study to analyze the distribution and interrelationship of proteasome peptidase activities, ubiquitin protein ligase activities and ubiquitin pools in mammalian tissue extracts obtained at physiologic baseline conditions. For the assessment of the proteasome, we studied chymotryptic- and tryptic-like peptidase activities in combination with the specific proteasome inhibitor epoxomicin and ATP/ $\mathrm{Mg}^{2+}$ depletion (Eytan et al. 1993, Meng et al. 1999). Due to the lack of representative test substrates for the ubiquitin protein ligase systems, we determined rates of ubiquitin ligation to the sum of extract proteins, as a result of the total ubiquitin protein ligase activity (Majetschak et al. 2000, Ponelies et al. 2005).

\section{Methods}

\section{Animal protocol}

All procedures were approved by the Institutional Animal Care and Use Committee and described in detail previously (Majetschak et al. 2004). Five farm-raised crossbred fasted swine (30-35 kg) were sedated with an intramuscular injection of $10 \mathrm{mg} / \mathrm{kg}$ ketamine and $1 \mathrm{mg} / \mathrm{kg}$ xylazine, instrumented with an intravenous catheter in the ear vein. Animals were sacrificed with an intravenous overdose of anesthetics. Vastus medialis muscle (fast glycolytic muscle with $\sim 70 \%$ type IIb fibers (Rusunen and Poulanne 1997)), heart (left ventricle), lung, liver, spleen and kidney were harvested, snap frozen in liquid nitrogen, and stored at $80{ }^{\circ} \mathrm{C}$.

\section{Preparation of tissue extracts}

Tissues were homogenized in ice-cold $1 / 10$ phosphate buffered saline, pH 7.4 (1:5; volume:volume) using a Brinkmann-Polytron homogenizer (Best-LabDeals, Raleigh, NC, USA). Homogenates were centrifuged $\left(20000 \mathrm{xg}, \quad 5^{\circ} \mathrm{C}, \quad 30 \mathrm{~min}\right)$, supernatants (extracts) were aliquoted, and protein concentration was measured (Lowry et al. 1951). One aliquot was immediately used for peptidase assays; all others were stored frozen at

$-80^{\circ} \mathrm{C}$ until further analysis.

\section{Western blot analyses}

Immunoblotting to ubiquitin with an antiubiquitin antibody and densitometric quantification was described in detail previously (Majetschak et al. 2003, Ponelies et al. 2005). In brief, lysate proteins were 
separated by SDS-polyacrylamide gel electrophoresis (4-15\% Tris- $\mathrm{HCl}$ gradient gels, Bio-Rad, Hercules, CA, USA), transferred to PVDF membranes and probed for ubiquitin with anti-ubiquitin antibody (1:800, Sigma, St. Louis, MO, USA) and a corresponding horseradish peroxidase labeled secondary antibody (1:10000, Amersham, Piscataway, NJ, USA). Visualization and quantification of immunoreactive proteins was performed with chemiluminescence detection (Super-Signal, Pierce, Rockford, IL, USA) using the ImageMaster VDS-CL system with the ImageQuant TL analysis software (Amersham).

Fifty $\mu \mathrm{g}$ extract from each tissue and, as standards for the quantification, lanes containing 10 and $20 \mathrm{ng}$ of ubiquitin were electrophoresed on each gel; $\mathrm{r}^{2}$ was $0.97-0.98$ for standard curves with ubiquitin. To prevent an underestimation of ubiquitin protein conjugates due to increased degradation or hydrolysis of ubiquitin chains in vitro, the intensities of the bands were compared in extracts prepared with and without addition of $7 \mu \mathrm{M}$ epoxomicin (Meng et al. 1999) and $3 \mu \mathrm{M}$ ubiquitin-aldehyde (Hershko and Rose 1987) (both from Boston Biochem, Boston, MA, USA) to the lysis buffer, a correction factor was determined for each tissue (liver 1.1 , muscle and heart -1.3 , spleen -1.4 , kidney -1.6 , lung -2) and applied for the calculation of the tissue levels. Dye stain analysis (MemCode Reversible Protein Stain, Pierce, Rockford, IL, USA) was performed as control for the protein transfer to the blotting membranes. Molecular mass standards (Precision Plus Protein Standards, Bio-Rad) were run on each gel.

\section{Proteasome peptidase assays}

Peptidase activities were measured employing the fluorogenic peptide substrates $N$-Suc-Leu-Leu-ValTyr-7-amino-4-methylcoumarin (chymotryptic-like) and Bz-Val-Gly-Arg-7-amino-4-methylcoumarin (trypticlike) (both from Plymouth Meeting, PA, USA). Reaction mixtures contained $1 \mathrm{mM}$ DTE, $1 \mathrm{mM}$ ATP, $5 \mathrm{mM}$ $\mathrm{MgCl}_{2}, 10 \mathrm{mM}$ Tris $/ \mathrm{HCl}, \mathrm{pH} 8.0,100 \mu \mathrm{M}$ peptide substrate and $0.6 \mathrm{mg} / \mathrm{ml}$ tissue extract prepared without epoxomicin and ubiquitin-aldehyde. Mixtures were incubated for $60 \mathrm{~min}$ at $37^{\circ} \mathrm{C}$. Ethanol $(2: 1$; volume: volume) was added, mixtures placed on ice for $10 \mathrm{~min}$ and centrifuged at $16000 \times g 5^{\circ} \mathrm{C}$ for $6 \mathrm{~min}$. Supernatants were transferred into microplates (Corning, Acton, MA, USA) and free 7-amino-4-methylcoumarin cleaved from the substrates was measured by a fluorescence reader (FLX8000, Biotek, Woburn, MA, USA, גexcitation/emission
360/455 nm) against standard curves of 7-amino-4methylcoumarin (Sigma). To differentiate the $\mathrm{Mg}^{2+} / \mathrm{ATP}$ dependent 26S-proteasome from other peptidase activities, the $\mathrm{Mg}^{2+} /$ ATP- and epoxomicin- (specific proteasome inhibitor) dependent proportion was determined by addition of $10 \mathrm{mM}$ EDTA (Sigma) and $7 \mu \mathrm{M}$ epoxomicin to the mixtures. Proteasome peptidase activity, determined as mol of 7-amino-4-methylcoumarin cleaved per second, was calculated (total peptidase activity minus activity in the presence of EDTA and epoxomicin) and specific activity expressed as mol. $\mathrm{s}^{-1} \cdot \mathrm{mg}^{-1}$ protein. Enzyme time-progression curves showed linearity for 60 minutes for the peptidase activities. Since pilot experiments showed that proteasome peptidase activities were inactivated by a single freeze ($80{ }^{\circ} \mathrm{C}$ )-thaw cycle, all peptidase activities were measured immediately in freshly prepared tissue extracts.

\section{Ubiquitin-protein ligation rates}

The total ubiquitin-protein ligation rates in tissue extracts were measured as incorporation of $\mathrm{N}$-terminal biotinylated ubiquitin (ubiquitin ${ }_{b}$; Boston Biochem) into the sum of the extract proteins, as described previously (Majetschak et al. 2000, Ponelies et al. 2005). Incubation mixtures contained $1 \mathrm{mM}$ DTE, $1 \mathrm{mM}$ ATP, $5 \mathrm{mM}$ $\mathrm{MgCl}_{2}, 10 \mathrm{mM}$ Tris $/ \mathrm{HCl}, 8 \mu \mathrm{g} / \mathrm{ml}$ ubiquitin $_{\mathrm{b}}$ and 2.5 $\mathrm{mg} / \mathrm{ml}$ tissue extract prepared without epoxomicin and ubiquitin-aldehyde at $\mathrm{pH} 8$. Mixtures were incubated for $0,5,10$ and $20 \mathrm{~min}$ at $37^{\circ} \mathrm{C}$. After incubation, Laemmli sample buffer $(50 \% \mathrm{v} / \mathrm{v})$ was added and the mixtures were boiled for $5 \mathrm{~min}$, and then separated by SDS-PAGE. As a standard, a lane containing $10 \mathrm{ng}$ of ubiquitin $\mathrm{b}_{\mathrm{b}}$ was electrophoresed on each gel. Immunoblotting and densitometric analysis were performed using a monoclonal anti-biotin antibody conjugated to horseradish peroxidase (New England BioLabs, Beverly, MA), as described. To control for variations in protein transfer to the PVDV membranes and staining intensities, the total lane intensity was considered as the overall

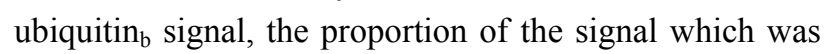
detectable in bands with a corresponding molecular mass of greater than $15 \mathrm{kDa}$ calculated and, as a baseline intensity correction, the corresponding intensity from the 0 min incubation mixture was subtracted. The specific ubiquitylation rate is given in mol ubiquitinBBBB ${ }_{\mathrm{bBBBB}}$ incorporated into cytosolic proteins per second $\left(\mathrm{mol} . \mathrm{mg}^{-1} \cdot \mathrm{s}^{-1}\right)$. For activity calculations from progress curves, the initial data points plus the origin were analyzed by nonlinear regression analysis. 
Table 1. Tissue levels of free and conjugated ubiquitin in porcine tissues.

\begin{tabular}{lll}
\hline Tissue & Free ubiquitin tissue level $(\boldsymbol{\mu g} / \mathbf{g})$ & Conjugated ubiquitin tissue level $(\boldsymbol{\mu g} / \mathbf{g})$ \\
\hline Muscle & $4.6 \pm 0.5^{\mathrm{a}}$ & $215 \pm 27^{\mathrm{a}}$ \\
Heart & $4.8 \pm 0.4^{\mathrm{a}}$ & $170 \pm 32^{\mathrm{a}}$ \\
Lung & $8.3 \pm 1.7^{\mathrm{b}}$ & $370 \pm 91^{\mathrm{a}}$ \\
Liver & $4.2 \pm 0.7^{\mathrm{a}}$ & $288 \pm 32^{\mathrm{a}}$ \\
Kidney & $4.3 \pm 0.7^{\mathrm{a}}$ & $270 \pm 40^{\mathrm{a}}$ \\
Spleen & $10.6 \pm 1.3^{\mathrm{b}}$ & $616 \pm 129^{\mathrm{b}}$ \\
\hline
\end{tabular}

$\mathrm{N}=5$ per tissue. Mean \pm S.E.M. Tissue levels are expressed as $\mu \mathrm{g} / \mathrm{g}$ tissue wet weight. Tissue levels not sharing the same letter are significantly different $(p<0.05$, ANOVA).

Table 2. Correlations between components of the ubiquitin proteasome pathway in porcine tissues.

\begin{tabular}{|c|c|c|c|c|}
\hline & $\begin{array}{l}\text { Conjugated Ub } \\
(\mu \mathrm{g} / \mathrm{g} \text { wet weight })\end{array}$ & $\begin{array}{l}\text { UbPL } \\
\left(\text { fmol } \cdot \mathbf{s}^{-1} \cdot \mathrm{mg}^{-1}\right)\end{array}$ & $\begin{array}{l}\text { CT-L } \\
\left(\mathrm{pmol} \cdot \mathrm{s}^{-1} \cdot \mathrm{mg}^{-1}\right)\end{array}$ & $\begin{array}{l}\text { T-L } \\
\left(\mathrm{pmol} \cdot \mathrm{s}^{-1} \cdot \mathrm{mg}^{-1}\right)\end{array}$ \\
\hline Free $U b(\mu g / g)$ & $0.438(0.016)$ & $0.568(0.002)$ & $-0.094(0.623)$ & $0.002(0.993)$ \\
\hline Conjugated Ub ( $\mu g / g)$ & & $0.410(0.03)$ & $-0.160(0.398)$ & $-0.093(0.626)$ \\
\hline$U b P L\left(\left[f m o l . s^{-1} \cdot m g^{-1}\right)\right.$ & & & $0.073(0.712)$ & $0.193(0.325)$ \\
\hline$C T-L\left(p m o l . s^{-1} \cdot m g^{-1}\right)$ & & & & $0.824(<0.001)$ \\
\hline
\end{tabular}

Data are Spearman's correlation coefficients $r_{s}(p)$

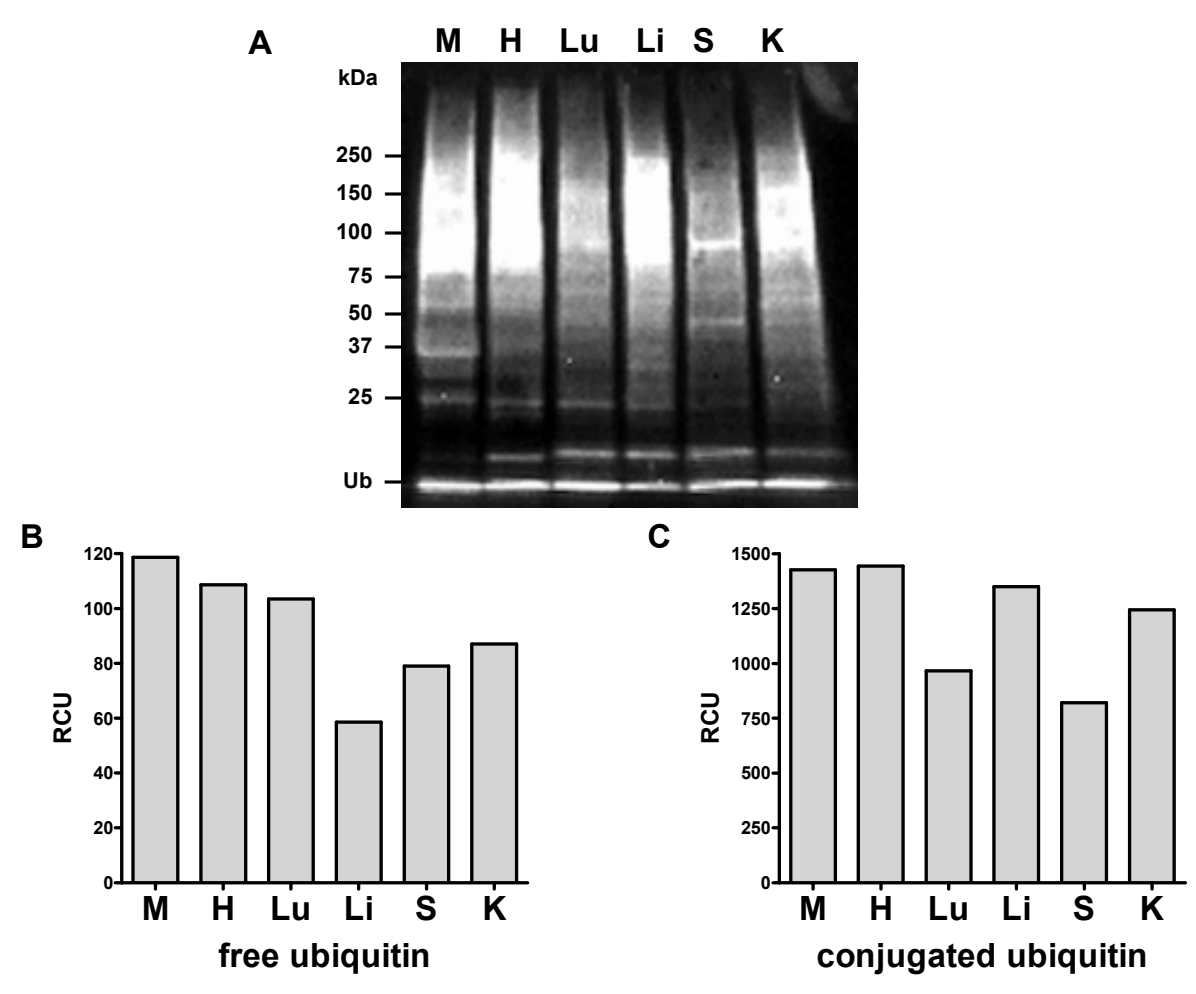

Fig. 1. A. Analyses of free ubiquitin and ubiquitin protein conjugates in tissue extracts by immunoblotting. Left: Molecular mass standards. Ub: Ubiquitin. Each lane contains $50 \mu \mathrm{g}$ of the following tissue extracts: M - Skeletal muscle; $\mathrm{H}$ - Heart; Lu - Lung; Li Liver, S - Spleen; K - Kidney. B. Densitometric quantification of free ubiquitin corresponding to $\mathbf{A}$. RCU: Relative chemiluminescence units. C. Densitometric quantification of conjugated ubiquitin corresponding to A. RCU: Relative chemiluminescence units. 


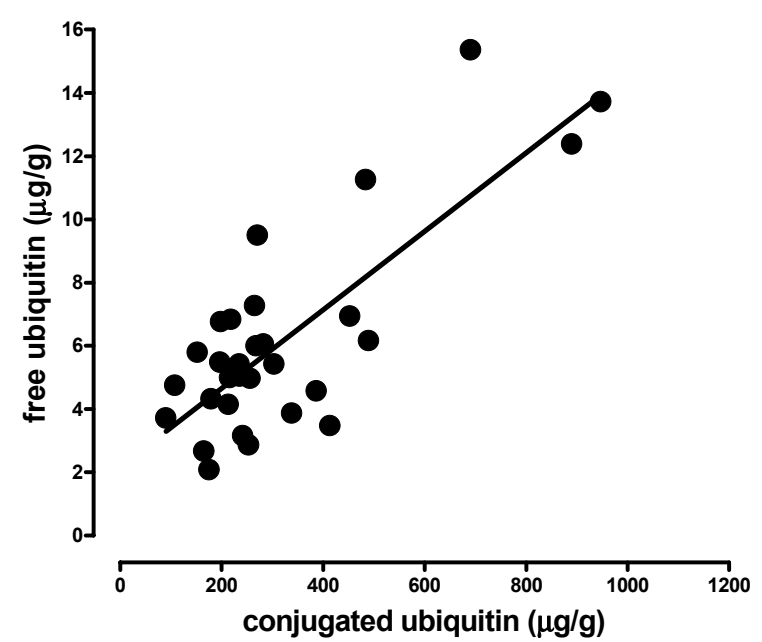

Fig. 2. Correlation between free and conjugated ubiquitin tissue levels $(\mu \mathrm{g} / \mathrm{g}$ wet weight). The regression line was calculated by linear regression analysis $\left(r^{2}=0.623, p<0.001\right)$.

\section{Statistics}

Data are described as the mean \pm SEM. One-way ANOVA and Spearman's correlation coefficients $\left(r_{s}\right)$ were calculated with the SPSS-program (SPSS, Chicago, IL, USA). Regression analyses were calculated with the GraphPad-Prism-program (GraphPad-Software, San Diego, CA, USA). A two-tailed $\mathrm{p}<0.05$ was considered significant.

\section{Results}

Figure 1A shows a representative blotting image of the various tissue extracts and Figure 1B the corresponding densitometric quantification of the chemiluminescence signals. The chemiluminescence signal for free ubiquitin was lowest in liver extract, whereas the signals for ubiquitin protein conjugates were lowest in lung and spleen extracts. The tissue levels per gram wet weight are summarized in Table 1. Levels of free ubiquitin varied 2.5-fold among the tissues. Tissue levels of free ubiquitin were similar in muscle, heart, liver and kidney and ranged between 4.3-4.8 $\mu \mathrm{g} / \mathrm{g}$. Significantly higher levels of free ubiquitin were detectable in lung and spleen $(8.3 \pm 1.7 \mu \mathrm{g} / \mathrm{g}$ and $10.6 \pm 1.3 \mu \mathrm{g} / \mathrm{g}$, respectively; $\mathrm{p}<0.05$ vs. all other organs). There was a 3.6 -fold difference between the highest (spleen $616 \pm 129 \mu \mathrm{g} / \mathrm{g}$ ) and lowest (heart $170 \pm 32 \mu \mathrm{g} / \mathrm{g}$ ) tissue level of conjugated ubiquitin. Tissue levels of conjugated ubiquitin were significantly higher in spleen than in all other organs ( $<<0.05 v s$. all other organs).

In all tissues, chymotryptic-like proteasome
A

\section{B}
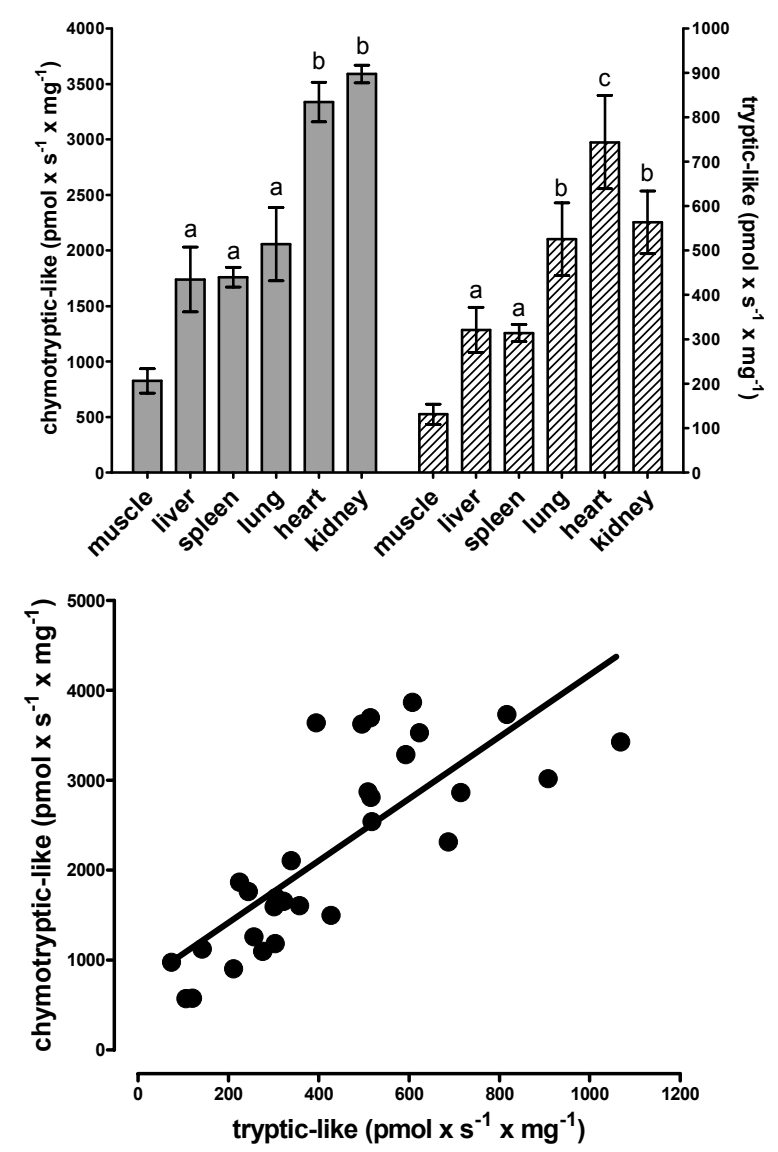

Fig. 3. A. Proteasome peptidase activities in tissue extracts. Mean \pm SEM; $n=5$ per tissue. Grey bars: Chymotryptic-like proteasome peptidase activities. Striped bars: Tryptic-like proteasome peptidase activities. Bars not sharing the same letter are significantly different ( $p<0.05$, ANOVA). B. Correlation between chymotryptic- and tryptic-like proteasome peptidase activities in the tissue extracts. The regression line was calculated by linear regression analysis $\left(r^{2}=0.624, p<0.001\right)$.

peptidase activity was higher than the tryptic-like activity. The specific chymotryptic- and tryptic-like proteasome peptidase activities (Fig. 3A) differed 4- to 6 -fold between tissues and were lowest in muscle $(\mathrm{p}<0.05$ for all comparisons). Intermediate proteasome peptidase activities were detectable in liver, spleen and lung extracts, while heart and kidney showed highest activities. Both proteasome peptidase activities correlated significantly (Table 2) and showed a linear relationship (Fig. 3B). Proteasome peptidase activities did not correlate with tissue levels of free or conjugated ubiquitin (Table 2).

The time course of the conjugation of ubiquitin to extract proteins is shown in Figure 4A. Ubiquitin protein ligation showed classical enzyme time progression curves in all tissue extracts. The ubiquitin protein ligation rates of the individual tissue extracts were 
A

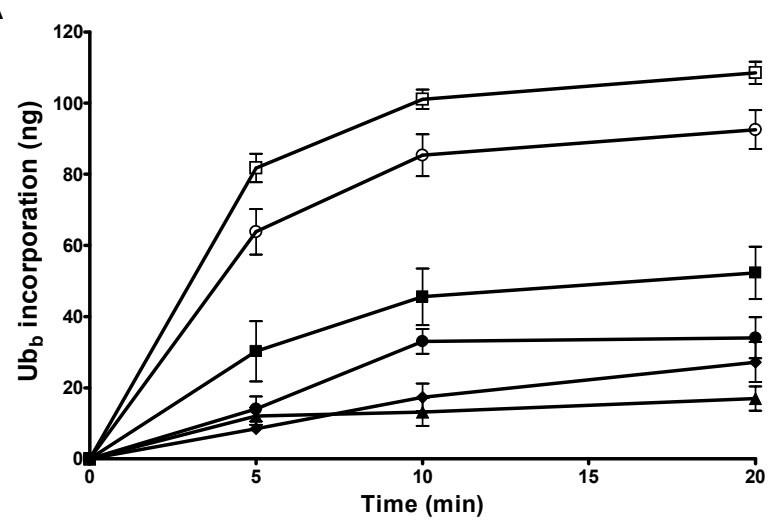

B

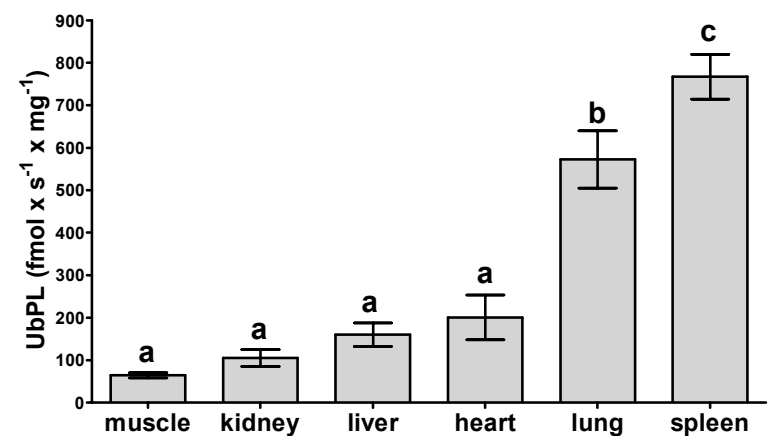

Fig. 4. A. Progress curves of the conjugation of ubiquitin $n_{b}$ to extract proteins in the various tissues. Values are mean \pm SEM, $n$ $=5$ per time point. $\diamond$ : Skeletal muscle. a: Heart. O: Lung. $\bullet$ : Liver. $\square$ : Spleen. $\boldsymbol{\Delta}$ : Kidney. B. Specific ubiquitin protein ligation rates (UbPL) resulting from $\mathbf{A}$. Mean $\pm \mathrm{SEM}, \mathrm{n}=5$ per tissue. Bars not sharing the same letter are significantly different $(p<0.05$, ANOVA).

calculated on the basis of initial progress curves (Fig. 4B). We detected a 13-fold variation among tissues. While muscle, kidney, liver and heart showed low ubiquitin protein ligation rates ranging between $64 \pm 6$ fmol.s $\mathrm{s}^{-1} \cdot \mathrm{mg}^{-1}$ (muscle) and $200 \pm 53 \mathrm{fmol} . \mathrm{s}^{-1} \cdot \mathrm{mg}^{-1}$ (heart), ubiquitylation rates were intermediate in lung extracts $\left(572 \pm 67 \mathrm{fmol} . \mathrm{s}^{-1} \cdot \mathrm{mg}^{-1}\right)$ and highest in spleen $(767 \pm 53$ fmol.s $\left.\mathrm{s}^{-1} \cdot \mathrm{mg}^{-1}\right)$.

Ubiquitin protein ligation rates did not correlate with proteasome peptidase activities (Table 2) but were significantly positive associated with tissue levels of free and conjugated ubiquitin (Table 2, Fig. 5).

\section{Discussion}

The present study provides the first systematic assessment of the tissue distribution and interrelationship of ubiquitin proteasome pathway component activities and tissue ubiquitin pools in physiologic baseline conditions. There are several new findings from this

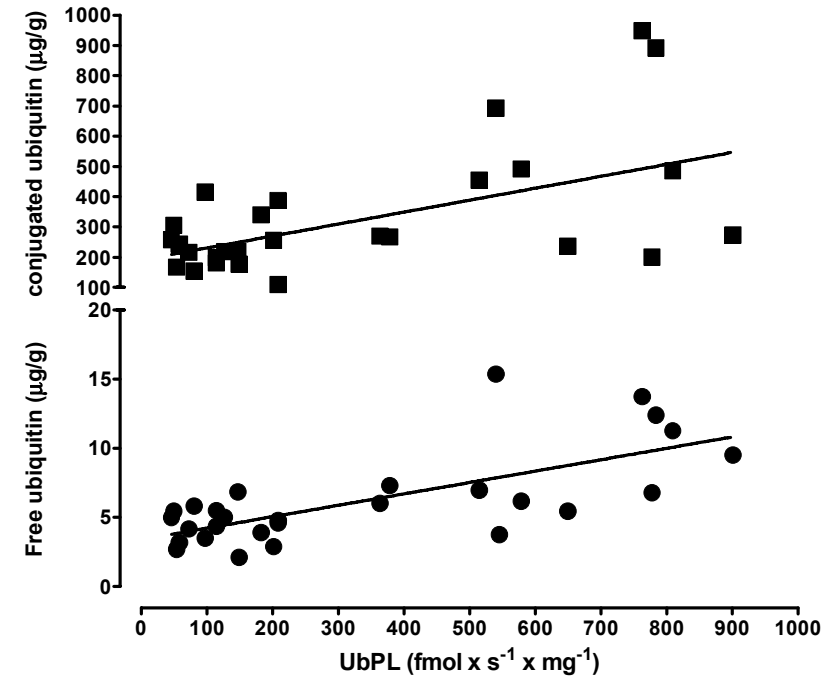

Fig. 5. Correlation between free (0) or conjugated (ם) ubiquitin tissue levels ( $\mu \mathrm{g} / \mathrm{g}$ wet weight) and specific ubiquitin protein ligation rates (UbPL). The regression lines were calculated by linear regression analyses (free ubiquitin: $r^{2}=0.493, p<0.001$; conjugated ubiquitin: $\left.r^{2}=0.28, p=0.0038\right)$.

study. First, tissue levels of free ubiquitin, conjugated ubiquitin and the corresponding ubiquitin protein ligation activities were significantly interrelated. Second, proteasome peptidase activities did not correlate with tissue ubiquitin pools or ubiquitin protein ligation rates. Third, there were considerable differences between organs, thus suggesting tissue-specific distribution patterns and roles of the system components. While lung and spleen were characterized by high tissue levels of free and conjugated ubiquitin and by high ubiquitin protein ligation activities, proteasome activities were highest in kidney and heart.

The finding of the present study that tissue levels of free and conjugated ubiquitin correlate significantly linear indicates that the fraction of conjugated ubiquitin is constant and similar in all tissues, which is in agreement with previous studies in a human lung fibroblast cell line (IMR-90) and in human peripheral blood mononuclear cells (Haas and Bright 1987, Ponelies et al. 2005).

Haas and Bright (1987) proposed a minimum kinetic model to approximate the dynamics of the intracellular ubiquitin pools:

ubiquitin + protein $\underset{k_{\text {dia }}}{\stackrel{k_{\text {form }}}{\longrightarrow}}$ ubiquitin - protein $\stackrel{k_{\text {deg }}}{\longrightarrow}$ ubiquitin + amino acids

in which $k_{\text {form }}, k_{\text {dia }}$ and $k_{\text {deg }}$ are the bulk rate constants for ubiquitin protein conjugate formation, conjugate disassembly and degradation, respectively. It was inferred that regulation of the ubiquitin conjugate pool size 
probably results from direct control of either ligation or disassembly rates, whereas potential modulation of $k_{d e g}$ would have little effects.

Applying this model to our study, ubiquitin protein ligation rates approximate the net bulk rate constant for ubiquitin (net $k_{\text {form }}=k_{\text {form }}-k_{\text {dia }}$ ). Assuming steady state conditions, the significant interrelationship between tissue ubiquitin pools and net $\mathrm{k}_{\text {form }}$ and the missing correlation between proteasome peptidase activities and ubiquitin pools supports the hypothesis that the effects of $k_{d e g}$ are probably small and further affirms that ubiquitin protein ligase systems and deubiquitylating enzymes are the major determinants of ubiquitin homeostasis.

Only a few previous studies have come to our attention that provided information on the tissue distribution of any one of the ubiquitin proteasome pathway component activities or ubiquitin pools. Methodological differences between the studies make a direct comparison of these data difficult. In line with previous studies in other species, we also found significant differences among the various porcine tissues. Goldstein et al. (1975) reported tissue levels of free ubiquitin comparable with our data in outbred mice, but several fold higher levels in the guinea pig. Our findings of high ubiquitin protein ligation rates in lung and low activities in skeletal muscle and liver are in agreement with the mRNA levels of E1 in human tissues, as detected by northern blotting (Handley et al. 1991), but do not correspond to the tissue differences in ubiquitylation rates determined in the rat (Rajapurohitam et al. 2002). Similarly, the high kidney and low skeletal muscle proteasome peptidase activities in our study are in agreement with measurements in the rat (Farout et al. 2000, 2003), whereas the relative proportions between other tissues were different. Besides methodological reasons, the discrepancies also point towards speciesspecific differences in tissue distribution patterns. Thus, further studies providing a comprehensive assessment of ubiquitin proteasome pathway component activities and ubiquitin pools in different species, and particularly in human tissues, are required.

There are several limitations of the present study. Amounts of ubiquitin pools were quantified by immunoblotting. More precise quantification procedures for tissue extracts, e.g. enzyme linked immunosorbent assays or radioimmunoassays, are not routinely available. However, densitometric quantification in this study was performed only on gels containing one lane of each individual tissue extract and the determined conjugate levels were corrected for in vitro disassembly. Thus, the relative distribution of ubiquitin pools among tissues should reflect their actual content. Furthermore, in the ubiquitylation assay, free ubiquitin and ubiquitin $_{b}$ compete as substrates for the ligation to endogenous proteins and tissue differences in free ubiquitin levels might influence the measurements of ubiquitin protein ligation rates in vitro. However, ubiquitin $\mathrm{b}_{\mathrm{b}}$ exceeded free endogenous ubiquitin in the incubation mixtures 17- to 68-fold and the actual concentration of free ubiquitin in the tissue extracts did not correlate with the corresponding ubiquitin protein ligation rates (data not shown). Thus, the measurements rather underestimate the high ubiquitylation rate in lung and the relatively low rates in liver. As for any proteasome activity assays in crude tissue extracts, our peptidase measurements permit only an indirect assessment. Since the omission of $\mathrm{Mg}^{2+}$ prevents 26S proteasome complex formation (Eytan et al. 1993) and epoxomicin is a specific and irreversible proteasome inhibitor (Meng et al. 1999), we assumed that the $\mathrm{Mg}^{2+} / \mathrm{ATP}$ - and epoxomicin- dependent proportion of the overall peptidase activities measured at $\mathrm{pH} 8.0$ sufficiently discriminates the proteasome from other proteases in crude tissue extracts. This approach prevents from creating conditions farther from a physiologic milieu, which are associated with partial proteasome purification procedures. On the other hand, it is certainly limited by a lower specificity and the differences in epoxomicin sensitivity for the tryptic- and chymotrypticlike activities (Meng et al. 1999, Bulteau et al. 2002, Rodgers and Dean 2003).

Finally, the physiological significance of the tissue-specific distribution patterns of ubiquitin proteasome pathway components remains to be determined. Nevertheless, the high proteasome peptidase activities in heart and kidney suggest a relevant role of the proteasome during health and disease states in these organs and may correspond to recent reports on beneficial effects of proteasome inhibition during ischemia and reperfusion. In models of myocardial ischemia reperfusion injury proteasome inhibitors were found to reduce postischemic creatine kinase levels, the area of myocardial infarction and to improve coronary flow and contractile function (Campbell et al. 1999, Bao et al. 2001, Pye et al. 2003). These beneficial effects in the heart may correspond to reduction of reperfusion induced myocardial NFKB activation, activation of the p38 MAP kinase pathway and the induction of a differential heat- 
shock response by proteasome inhibition (Pye et al. 2003, Luss et al. 2002, Stangl et al. 2002). In the kidney, proteasome inhibition attenuated ischemia-reperfusion associated renal dysfunction, reduced histological lesions and prevented an increase in endothelin-1 production (Itoh et al. 2001, Takaoka et al. 1999).

Furthermore, high ubiquitin-protein ligation rates in spleen are in agreement with the known importance of ubiquitylation in the immune system (BenNeriah 2002, Liu et al. 2005). Based on the high ubiquitin-protein ligation rates in the lung, we infer that the ubiquitin proteasome pathway, and ubiquitin-protein ligase systems in particular, are also of major importance in pulmonary physiology. This finding could correspond to a recent report that showed lung toxicity during myeloma therapy with the proteasome inhibitor bortezomib in Japanese patients (Miyakoshi et al. 2006).

In conclusion, the present study shows that tissue ubiquitin pools are tightly regulated at physiological baseline conditions and indicates a constant proportion of conjugated ubiquitin. We provide further experimental evidence for the hypothesis that ubiquitin protein ligase systems and probably deubiquitylating enzymes are the key regulators of ubiquitin homeostasis. The considerable differences in tissue distribution are suggestive of important tissue specific roles of ubiquitin proteasome pathway components in health and disease states. Besides the known importance of the ubiquitin system in the heart, kidney and in the immune system, our findings also identified the lung as an organ in which perturbations in components of the ubiquitin proteasome pathway may contribute to disease processes and could possibly be targeted for therapeutic intervention.

\section{Acknowledgements}

We thank Lissette T. Busby for excellent technical help. This research was supported in part by a grant from the Deutsche Forschungsgemeinschaft (DFG MA 2474/2-1 and 2-2 to M.M.) and funds from the DeWitt Daughtry Family Department of Surgery.

\section{References}

BAO J, SATO K, LI M, GAO Y, ABID R, AIRD W, SIMONS M, POST MJ: PR-39 and PR-11 peptides inhibit ischemia-reperfusion injury by blocking proteasome-mediated I kappa B alpha degradation, Am J Physiol 281: H2612-H2618, 2001.

BAUMEISTER W, WALZ J, ZÜHL F, SEEMÜLLER E: The proteasome: paradigm of a self-compartmentalizing protease. Cell 92: 367-380, 1998.

BEN-NERIAH Y: Regulatory functions of ubiquitination in the immune system. Nat Immunol 1: 20-26, 2002.

BULTEAU AL, PETROPOULOS I, FRIGUET B: Age-related alterations of proteasome structure and function in aging epidermis. Exp Gerontol 35: 767-777, 2002.

CAMPBELL B, ADAMS J, SHIN YK, AND LEFER AM: Cardioprotective effects of a novel proteasome inhibitor following ischemia and reperfusion in the isolated perfused rat heart. J Mol Cell Cardiol 31: 467-476, 1999.

DERUISSEAU KC, KAVAZIS AN, DEERING MA, FALK DJ, VAN GAMMEREN D, YIMLAMAI T, ORDWAY GA, POWERS SK: Mechanical ventilation induces alterations of the ubiquitin-proteasome pathway in the diaphragm. J Appl Physiol 98: 1314-1321, 2005.

EYTAN E, ARMON T, HELLER H, BECK S, HERSHKO A: Ubiquitin C-terminal hydrolase activity associated with the $26 \mathrm{~S}$ protease complex. J Biol Chem 268: 4668-4674, 1993.

FAROUT L, LAMARE MC, CARDOZO C, HARRISSON M, BRIAND Y, BRIAND M: Distribution of proteasomes and of the five proteolytic activities in rat tissues. Arch Biochem Biophys 374: 207-212, 2000.

FAROUT L, LAMARE M, CLAVEL S, BRIAND M, BRIAND Y: Differential expression of ubiquitin and proteasome-dependent pathway components in rat tissues. Comp Biochem Physiol B Biochem Mol Biol 134: 297-305, 2003.

GOLDSTEIN G, SCHEID M, HAMMERLING U, SCHLESINGER DH, NIALL HD, BOYSE EA: Isolation of a polypeptide that has lymphocyte-differentiating properties and is probably represented universally in living cells. Proc Natl Acad Sci USA 72: 11-15, 1975.

HAAS AL, BRIGHT PM: The dynamics of ubiquitin pools within cultured human lung fibroblasts. $J$ Biol Chem 262: 345-351, 1987. 
HANDLEY PM, MUECKLER M, SIEGEL NR, CIECHANOVER A, SCHWARTZ AL: Molecular cloning, sequence, and tissue distribution of the human ubiquitin-activating enzyme E1. Proc Natl Acad Sci USA 88: 258-262, 1991.

HANNA J, LEGGETT DS, FINLEY D: Ubiquitin depletion as a key mediator of toxicity by translational inhibitors. Mol Cell Biol 23: 9251-9261, 2003.

HASSELGREN PO: Catabolic response to stress and injury: implications for regulation. World J Surg 24: 1452-1459, 2000.

HERSHKO A, CIECHANOVER A: The ubiquitin system. Annu Rev Biochem 67: 425-479, 1998.

HERSHKO A, ROSE IA: Ubiquitin-aldehyde: a general inhibitor of ubiquitin-recycling processes. Proc Natl Acad Sci USA 84: 1829-1833, 1987.

ITOH M, TAKAOKA M, SHIBATA A, OHKITA M, MATSUMURA Y: Preventive effect of lactacystin, a selective proteasome inhibitor, on ischemic acute renal failure in rats. J Pharmacol Exp Ther 298: 501-507, 2001.

JAGOE RT, GOLDBERG AL: What do we really know about the ubiquitin-proteasome pathway in muscle atrophy? Curr Opin Clin Nutr Metab Care 4: 183-190, 2001.

KISSELEV AF, GOLDBERG AL: Monitoring activity and inhibition of $26 \mathrm{~S}$ proteasomes with fluorogenic peptide substrates. Methods Enzymol 398: 364-378, 2005.

KUKAN M: Emerging roles of proteasomes in ischemia-reperfusion injury of organs. J Physiol Pharmacol 55: 3-15, 2004.

LIU YC, PENNINGER J, KARIN M: Immunity by ubiquitylation: a reversible process of modification. Nat Rev Immunol 5: 941-952, 2005.

LOWRY OH, ROSEBROUGH NJ, FARR AL, RANDALL RJ: Protein measurement with the Folin Phenol reagent. J Biol Chem 193: 265-275, 1951.

LUSS H, SCHMITZ W, NEUMANN J: A proteasome inhibitor confers cardioprotection. Cardiovasc Res 54: 140-151, 2002.

MAJETSCHAK M, COHN SM, OBERTACKE U, PROCTOR KG: Therapeutic potential of exogenous ubiquitin during resuscitation from severe trauma. J Trauma 56: 991-1000, 2004.

MAJETSCHAK M, KREHMEIER U, BARDENHEUER M, DENZ C, QUINTEL M, VOGGENREITER G, OBERTACKE U: Extracellular ubiquitin inhibits the TNF $\alpha$ response to endotoxin in peripheral blood mononuclear cells and regulates endotoxin hyporesponsiveness in critical illness. Blood 101: 1882-1890, 2003.

MAJETSCHAK M, SUCIU DM, HASLER K, OBERTACKE U, SCHADE FU, JENNISSEN HP: Cytosolic protein ubiquitylation in normal and endotoxin stimulated human peripheral blood mononuclear cells. $J$ Endotoxin Res 6: 483-488, 2000.

MENG L, MOHAN R, KWOK BH, ELOFSSON M, SIN N, CREWS CM: Epoxomicin, a potent and selective proteasome inhibitor, exhibits in vivo antiinflammatory activity. Proc Natl Acad Sci USA 96: 10403-10408, 1999.

MIYAKOSHI S, KAMI M, YUJI K, MATSUMURA T, TAKATOKU M, SASAKI M, NARIMATSU H, FUJII T, KAWABATA M, TANIGUCHI S, OZAWA K, OSHIMI K: Severe pulmonary complications in Japanese patients after bortezomib treatment for refractory multiple myeloma. Blood [Epub ahead of print]: Jan 12, 2006.

ORLOWSKI M: The multicatalytic proteinase complex a major extralysosomal proteolytic system. Biochemistry 29: 10289-10297, 1990.

PONELIES N, KREHMEIER U, HIRSCH T, DENZ C, PATEL MB, MAJETSCHAK M: Cytosolic ubiquitin levels and ubiquitylation rates in human peripheral blood mononuclear cells during sepsis. Shock 24: 20-25, 2005.

PYE J, ARDESHIRPOUR F, MCCAIN A, BELLINGER DA, MERRICKS E, ADAMS J, ELLIOTT PJ, PIEN C, FISCHER TH, BALDWIN AS JR, NICHOLS TC: Proteasome inhibition ablates activation of NF- $\kappa$ B in myocardial reperfusion and reduces reperfusion injury. Am J Physiol 284: H919-H926, 2003.

RAJAPUROHITAM V, BEDARD N, WING SS: Control of ubiquitination of proteins in rat tissues by ubiquitin conjugating enzymes and isopeptidases. Am J Physiol 282: E739-E745, 2002.

RIVETT AJ: Proteasomes: multicatalytic proteinase complexes. Biochem J 291: 1-10, 1993. 
RODGERS KJ, DEAN RT: Assessment of proteasome activity in cell lysates and tissue homogenates using peptide substrates. Int J Biochem Cell Biol 35: 716-727, 2003.

RUSUNEN M, POULANNE E: Comparison of histochemical properties of different pig breeds. Meat Sciences 45: 119$125,1997$.

SIGISMUND S, POLO S, DI FIORE PP: Signaling through monoubiquitination. Curr Top Microbiol Immunol 286: 149-185, 2004.

STANGL K, GUNTHER C, FRANK T, LORENZ M, MEINERS S, ROPKE T, STELTER L, MOOBED M, BAUMANN G, KLOETZEL PM, STANGL V: Inhibition of the ubiquitin-proteasome pathway induces differential heat-shock protein response in cardiomyocytes and renders early cardiac protection. Biochem Biophys Res Commun 291: 542-549, 2002.

TAKAOKA M, ITOH M, HAYASHI S, KURO T, MATSUMURA Y: Proteasome participates in the pathogenesis of ischemic acute renal failure in rats. Eur J Pharmacol 384: 43-46, 1999.

WEISSMAN AM: Themes and variations on ubiquitylation. Nat Rev Mol Cell Biol 2: 169-178, 2001.

\section{Corresponding author}

Matthias Majetschak, DeWitt Daughtry Family Department of Surgery, Divisions of Trauma and Surgical Critical Care, University of Miami Miller School of Medicine, 1800 NW 10th Ave., Miami, FL 33136, USA. Fax: +1 3052437354. E-mail:mmajetschak@med.miami.edu. 